\title{
Attrition Resistant Fischer-Tropsch Catalysts Based On FCC Supports
}

\author{
Final Report \\ Work Performed Under \\ Grant No. DE-FG26-06NT42744 \\ for \\ U.S. Department of Energy \\ National Energy Technology Laboratory \\ Pittsburgh, PA 15236 \\ by \\ Dr. Adeyinka A. Adeyiga \\ Department of Chemical Engineering \\ Hampton University \\ Hampton, VA 23668 \\ and \\ Dr. Jerry J. Spivey \\ Department of Chemical Engineering \\ Louisiana State University \\ Baton Rouge, LA 70803
}

May 2010 


\section{DISCLAIMER}

This report was prepared as an account of work sponsored by an agency of the United States Government. Neither the United States Government nor any agency thereof, nor any of their employees, makes any warranty, express or implied, or assumes any legal liability or responsibility for the accuracy, completeness, or usefulness of any information, apparatus, product, or process disclosed, or represents that its use would not infringe privately owned rights. Reference herein to any specific commercial product, process, or service by trade name, trademark, manufacturer, or otherwise, does not necessarily constitute or imply its endorsement, recommendation, or favoring by the United States Government or any agency thereof. The views and opinions of authors expressed herein do not necessarily state or reflect those of the United States Government or any agency thereof. 


\begin{abstract}
Commercial spent fluid catalytic cracking (FCC) catalysts provided by Engelhard and Albemarle were used as supports for Fe-based catalysts with the goal of improving the attrition resistance of typical F-T catalysts. Catalysts with the Ruhrchemie composition $(100 \mathrm{Fe} / 5 \mathrm{Cu} / 4.2 \mathrm{~K} / 25$ spent $\mathrm{FCC}$ on mass basis) were prepared by wet impregnation. XRD and XANES analysis showed the presence of $\mathrm{Fe}_{2} \mathrm{O}_{3}$ in calcined catalysts. $\mathrm{FeC}_{\mathrm{x}}$ and $\mathrm{Fe}_{3} \mathrm{O}_{4}$ were present in the activated catalysts. The metal composition of the catalysts was analyzed by ICP-MS. F-T activity of the catalysts activated in situ in $\mathrm{CO}$ at the same conditions as used prior to the attrition tests was measured using a fixed bed reactor at $\mathrm{T}=573 \mathrm{~K}, \mathrm{P}=1.38 \mathrm{MPa}$ and $\mathrm{H}_{2}: \mathrm{CO}$ ratio of $0.67 . \mathrm{Cu}$ and $\mathrm{K}$ promoted $\mathrm{Fe}$ supported over Engelhard provided spent FCC catalyst shows relatively good attrition resistance $\left(8.2 \mathrm{wt} \%\right.$ fines lost), high $\mathrm{CO}$ conversion $(81 \%)$ and $\mathrm{C}_{5}+$ hydrocarbons selectivity $(18.3 \%)$.
\end{abstract}

Keywords: Fischer-Tropsch synthesis, spent FCC materials, Attrition, Jet-cup 


\section{ACKNOWLEDGEMENTS}

This work was financially supported by U.S. DOE under HBCU/UCR program (contract no: DE-FG26-06NT42744), with the Süd-Chemie Inc industrial collaboration. The authors would like to acknowledge with gratitude the guidance provided by the DOE Contracting Officer's Representatives, Drs. Steven Markovich and Robert M. Kornosky. We thank Dr. Troy Walsh for his help in conducting attrition tests. Spent FCC supports provided by Engelhard and Albemarle Corporation is highly acknowledged. We would like to acknowledge CAMD, LSU for their help to carry out the XANES experiments. 
1.0 INTRODUCTION: PROBLEM DEFINITION .....................

2.0 EXECUTIVE SUMMARY .................................... 3

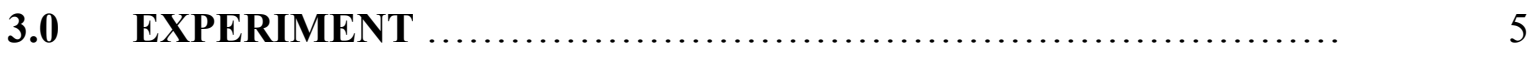

31 Catalyst Preparation........................................ 5

3.2 Catalyst Activation....................................... 6

3.3 Catalyst Characterization.................................... 6

3.4 Attrition Test.................................................

3.5 Activity Studies.........................................

4.0 RESULTS AND DISCUSION ................................. 9

4.1 Textural Properties and Metal Analysis.......................... 9

4.2 TPR Results........................................... 12

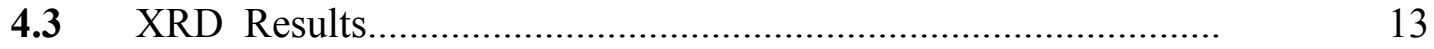

4.4 XANES Results......................................... 14

4.5 Attrition Results............................................

4.6 F-T Activity Results......................................... 17

5.0 CONCLUSION .....................................................

References............................................ 27

\section{List of Figures}

Figure-1: Pore size distribution curves of spent FCC supports, calcined and activated..... 11

$\mathrm{Fe}-\mathrm{Cu}-. . \mathrm{K} /$ spent FCC catalysts

Figure-2: $\mathrm{H}_{2}$-TPR profiles of $\mathrm{Cu}, \mathrm{K}$ promoted Fe supported over spent $\mathrm{FCC}$ catalysts and... 12 pure spent FCC supports

Figure-3: Powder X-ray diffraction patterns of (a) calcined catalysts and.......... 15

(b) $\mathrm{CO}$ activated catalysts

Figure-4: Normalized Fe K-edge XANES of Fe standards, calcined................. 16 and activated $\mathrm{Fe}-\mathrm{Cu}-\mathrm{K} /$ spent $\mathrm{FCC}$ catalysts 


\section{list of Figures (Contd)}

Figure-5: $\mathrm{CO}$ and $\mathrm{H}_{2}$ conversion as a function of time on stream................ 18

Figure-6: Selectivity of $\mathrm{CO}_{2}$ and $\mathrm{CH}_{4}$ with time on stream.................. 21

Figure-7: Selectivity of $\mathrm{C}_{2}-\mathrm{C}_{4}$ hydrocarbons with time on stream............... 22

Figure-8: Anderson-Schulz-Flory plot of chain growth..................... 23

\section{List of Tables}

Table 1. Textural properties of the catalysts...................................... 8

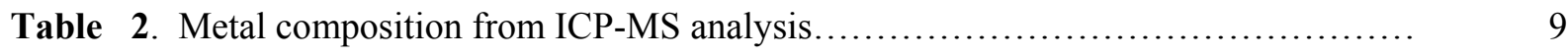

Table 3. Least squares fitting results for calcined and activated $\mathrm{Fe}-\mathrm{Cu}-\mathrm{K} /$ spent $\ldots \ldots \ldots \ldots \quad 16$ FCC catalysts

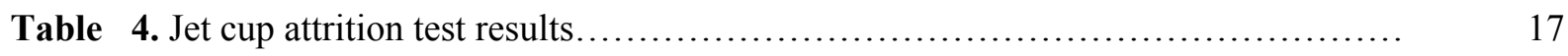

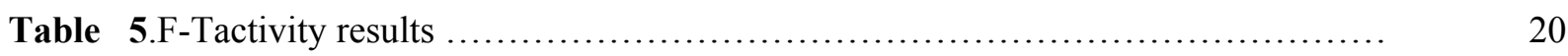

Table 6. Oxygenate product distribution in aqueous samples........................ 24 


\section{NOMENCLATURE}

$\begin{array}{ll}\text { (P) } & \text { Precipitated } \\ \text { (B) } & \text { Binder } \\ \text { CAER } & \text { Center of Advanced Energy Research } \\ \text { NETL } & \text { National Energy Technology Laboratory } \\ \text { SBCR } & \text { Slurry Bubble Column Reactor } \\ \text { WGS } & \text { Water Gas Shift } \\ \text { XRD } & \text { X-Ray Powder Diffraction } \\ \text { TPR } & \text { Temperature Programmed Reduction } \\ \text { SEM } & \text { Scanning Electron Microscope } \\ \text { EDXS } & \text { Energy Dispersive X-Ray Spectroscopy } \\ \text { PSD } & \text { Particle Size Distribution } \\ \text { FTS } & \text { Fischer-Tropsch Synthesis } \\ \text { TOS } & \text { Time on Stream } \\ \text { STSR } & \text { Stirred Tank Reactor }\end{array}$




\section{ATTRITION RESSISTANT FISCHER-TROPSCH CATALYSTS BASED ON FCC SUPPORTS}

\subsection{Introduction: Problem Definition}

Clean, efficient fuels can be produced using the Fischer-Tropsch Synthesis (FTS), which is the reaction of $\mathrm{CO}$ and $\mathrm{H}_{2}$ (syngas), typically using iron-or cobalt-based catalysts. A number of plants are currently either under construction or in the planning stage (Table 1; Anon, 2004).

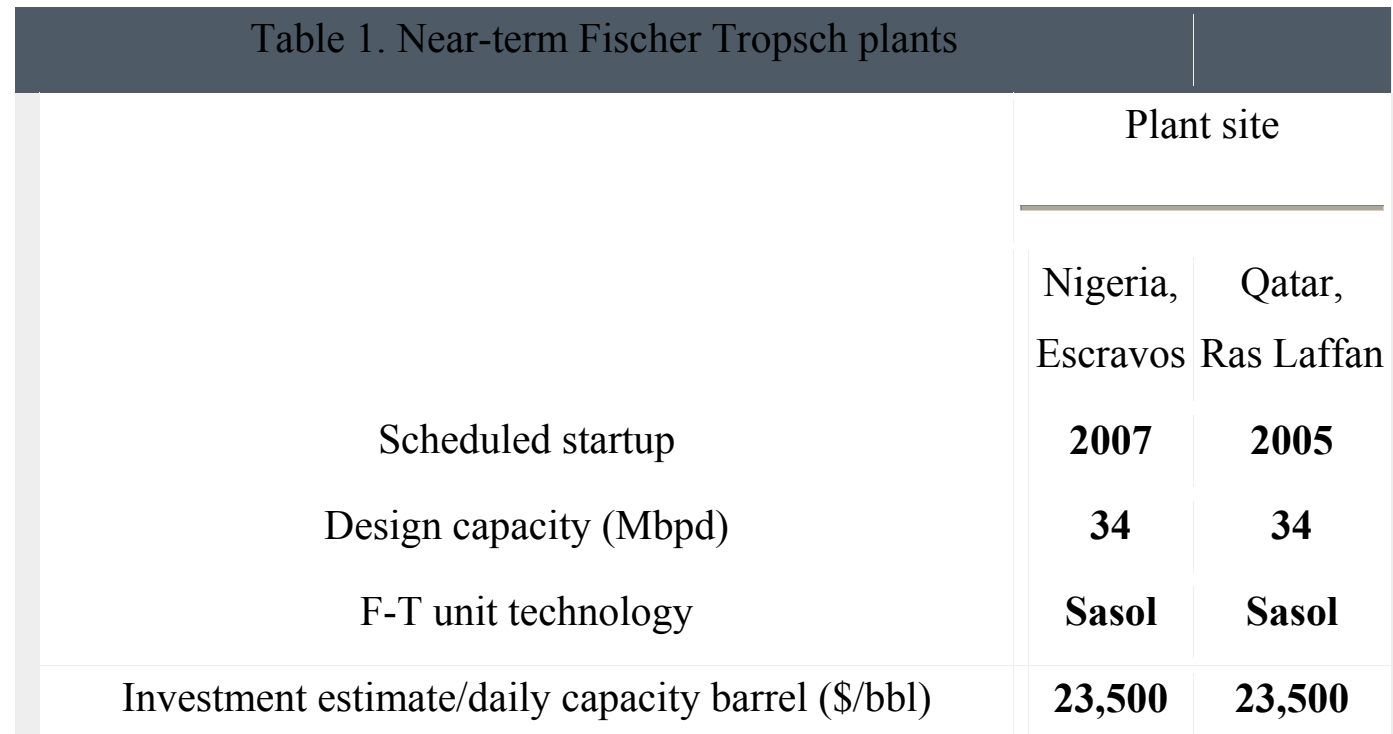

In addition to Sasol's coal-based FT plants in South Africa, two natural gas-based plants have been operating over the past 10 years: Shell's 15,000 b/d plant at Bintulu, Malaysia and a government-owned 20,000 b/d plant at Moss Bay in South Africa (Thackery, 2004). At least 24 proposals for FT projects have been announced in the past two years, most for large plants of $100,000 \mathrm{~b} / \mathrm{d}$ or more. These activities clearly show that improvements and innovations in FTS are underway. Given recent trends in energy prices, FTS is likely to be even more important to the production of clean fuels.

Coal-based FTS. This process is also strategically important to the U.S. because of its vast coal reserves, and because FTS represents the best means to make high quality transportation fuels and liquid products from coal. In addition to other technical issues, heat removal is a major reactor design challenge. Recent progress in this area has focused on the use of a slurry bubble 
column reactor (SBCR), originally developed comercially in the early 1990's by Sasol. A 5-m diameter, $2500 \mathrm{~b} / \mathrm{d}$ was brought on line during this time and operated for 10 years (Davis, 2003). These reactors are conceptually simple and inexpensive, but still permit high catalyst and reactor productivity. It is generally thought that this will be the reactor of choice for commercial, coalbased FTS in the United States.

Since modern coal gasification plants produce a syngas that is relatively lean in $\mathrm{H}_{2}$ $\left(\mathrm{H}_{2} / \mathrm{CO} \cong 0.5-0.7\right)$, a catalyst which is active for the FTS reaction $\left(\mathrm{CO}+2 \mathrm{H}_{2} \rightarrow-\mathrm{CH}_{2^{-}}+\mathrm{H}_{2} \mathrm{O}\right)$ and the water-gas shift (WGS) reaction $\left(\mathrm{CO}+\mathrm{H}_{2} \mathrm{O} \leftrightarrows \mathrm{CO}_{2}+\mathrm{H}_{2}\right)$ is required. The overall reaction on these catalysts is thus $2 \mathrm{CO}+\mathrm{H}_{2} \rightarrow-\mathrm{CH}_{2^{-}}+\mathrm{CO}_{2}$. This allows the efficient use of low $\mathrm{H}_{2} / \mathrm{CO}$ syngas. Iron-based catalysts, which are active shift catalysts, are thus preferred over cobalt-based catalysts; which are not. Iron is also much less expensive than cobalt.

There are two major barriers to the widespread commercialization of FTS using SBCRs:

(i) severe attrition of currently available iron-based catalysts. This attrition causes plugging, fouling, difficulty in separating the catalyst from the wax product, and loss of the catalyst. Each of these effects can result in very poor process economics.

(ii) production of a non-selective product slate of $\mathrm{C}_{1}$ to $\mathrm{C}_{60}{ }^{+}$hydrocarbons, requiring expensive downstream separation and processing, again resulting in poor economics.

This project addresses both of these two barriers by developing attrition-resistant chain-limiting iron-based F-T catalysts for SBCRs that maximize the production of $\mathrm{C}_{10}$ to $\mathrm{C}_{20}$ hydrocarbons, while limiting the production of light gases and $\mathrm{C}_{20}{ }^{+}$hydrocarbons.

Hampton University, in collaboration with Louisiana State University, has put together an exceptional research team. Also, a major commercial catalyst manufacturer, SUD CHEMIE, INC, will be providing guidance to the project and cost sharing. 


\subsection{EXECUTIVE SUMMARY}

Fischer-Tropsch (F-T) technology can be briefly defined as the means used to convert coal or natural gas derived synthesis gas containing $\mathrm{H}_{2}$ and $\mathrm{CO}$ into clean hydrocarbons using iron or cobalt based catalysts [1-3]. This can be expressed as (eq $\left.{ }^{\mathrm{n}}-1\right)$,

$$
(2 \mathrm{n}+1) \mathrm{H}_{2}+\mathrm{nCO} \longrightarrow \mathrm{C}_{\mathrm{n}} \mathrm{H}_{2 \mathrm{n}+2}+\mathrm{nH} 2 \mathrm{O} \text {---- (1) }
$$

For coal derived syngas, which typically has a low $\mathrm{H}_{2} / \mathrm{CO}$ ratio of $0.5-0.7$, Fe-based catalysts are preferred for F-T synthesis over cobalt-based catalysts due to iron's excellent watergas shift (WGS) activity (eq $\left.{ }^{\mathrm{n}}-2\right)$ and their low cost $[4,5]$.

$$
\mathrm{CO}+\mathrm{H}_{2} \mathrm{O} \longrightarrow \mathrm{CO}_{2}+\mathrm{H}_{2} \quad----
$$

However, catalyst attrition, causing plugging of downstream filters, product contamination and increased slurry viscosity, which leads to mass transfer limitations and eventually reactor shutdown is one of the major problems encountered with the industrial application of the Fe F-T catalysts in the slurry bubble column reactors (SBCRs) [6, 7]. A SBCR has been considered as the preferred industrial reactor for the F-T synthesis due to its low capital cost, low pressure drop across the reactor, excellent heat transfer efficiency and capability of online catalyst addition and removal $[8,9]$. Fe-based catalysts are known to undergo attrition during exposure to syngas at elevated temperatures [10] and their resistance to attrition must be improved for use in SBCRs.

In recent years, several research groups have studied attrition properties of iron based F-T catalysts $[4,11-13]$. The major relevant finding from previous studies has been that precipitated unsupported Fe F-T catalysts disintegrate easily into smaller particles $[6,14,15]$. In several studies it was found that even some spray-dried Fe F-T catalysts are not attrition resistant [12, 16-18]. However, Goodwin and coworkers [4, 13, 19], and Pham and coworkers [11, 15] were 
able to prepare Fe based F-T catalysts of sufficient attrition resistance using a spray drying method.

Gangwal et al., claimed that Fe or Co impregnated over spent fluid catalytic cracking (FCC) catalysts poisoned with heavy metals such as $\mathrm{Ni}$ and $\mathrm{V}$ were active in F-T synthesis and are attrition resistant [20]. They used commercial spent FCC catalysts as the supports without any further regeneration or passivation. Also they reported that spent FCC catalysts are more attrition resistant than fresh FCC catalysts. FCC is a particularly well known and widely used process in the oil refineries to crack the heavy oil into smaller hydrocarbon chains used to produce gasoline and heating oil. FCC catalysts are typically composed of $5-40 \%$ zeolite Y dispersed in a matrix of synthetic silica-alumina, semi-synthetic clay derived gel or kaolin clay $[21,22]$. Worldwide, the production of this important class of catalysts is about 300,000 tons/year for $350 \mathrm{FCC}$ units worldwide [22], 500 tons/day of which spent FCC catalyst is disposed after use. Only 5\% of this finds reuse in applications such as cement, asphalt and brick and the remainder is disposed as landfills [20, 22]. With growing environmental concern, land filling is becoming more costly and increasingly less desirable. The use of spent FCC catalyst is advantageous in both economical and environment aspects, due to its low cost and reuse of waste catalyst. Further, the presence of zeolite might improve the selectivity of F-T products towards $\mathrm{C}_{5}-\mathrm{C}_{12}$ hydrocarbons [23].

The objective of the present research is to study the role of spent FCC catalysts as supports for Fe F-T catalysts to improve their resistance to attrition and to study their F-T activity. However, improvement in attrition resistance at the expense of activity and selectivity is not desirable. 


\subsection{Experimental}

F-T synthesis was studied in a fixed bed reactor at a temperature of $573 \mathrm{~K}$ and pressure equals to $1.38 \mathrm{MPa}$. Nominal Ruhrchemie catalyst composition $100 \mathrm{Fe} / 5 \mathrm{Cu} / 4.2 \mathrm{~K} / 25 \mathrm{SiO}_{2}$ (on a mass basis) was taken as a baseline to synthesize the catalysts. These catalysts were prepared by incipient wetness replacing $\mathrm{SiO}_{2}$ with spent FCC material as a support. The Ruhrchemie catalyst is a robust precipitated iron catalyst for the F-T synthesis and was used initially in commercial fixed bed reactors at Sasol in South Africa [24, 25]. Two different commercial spent FCC catalysts were procured from Engelhard and Albemarle Corporation for this purpose and were used in this study without any further modification.

\subsection{Catalysts Preparation}

The catalysts were prepared by wet impregnation method to get Ruhrchemie composition $\left(100 \mathrm{Fe} / 5 \mathrm{Cu} / 4.2 \mathrm{~K} / 25 \mathrm{SiO}_{2}\right)$. The active metals were impregnated on to the spent $\mathrm{FCC}$ support step wise in the sequence of $\mathrm{K}, \mathrm{Fe}$ and $\mathrm{Cu}$. In a typical experiment, the requisite amount of $\mathrm{KHCO}_{3}$ dissolved in $\mathrm{H}_{2} \mathrm{O}$ was added to the spent FCC support. The excess water was removed using rotary evaporator under vacuum and at $363 \mathrm{~K}$ and continued for $2 \mathrm{~h}$. After cooling to room temperature, an aqueous solution of $\mathrm{Fe}\left(\mathrm{NO}_{3}\right)_{3} \cdot 9 \mathrm{H}_{2} \mathrm{O}$ was added slowly and excess water was removed using the rotary evaporator. Then an aqueous solution of $\mathrm{Cu}\left(\mathrm{NO}_{3}\right)_{2} 2.5 \mathrm{H}_{2} \mathrm{O}$ was added slowly to the catalyst and the drying procedure was repeated. Then the catalyst was dried in oven at $393 \mathrm{~K}$ for $5 \mathrm{~h}$ and calcined in air at $723 \mathrm{~K}$ for $2 \mathrm{~h}$. The catalysts were designated as $\mathrm{Fe}-\mathrm{Cu}-$ $\mathrm{K} /$ Engelhard and $\mathrm{Fe}-\mathrm{Cu}-\mathrm{K} / \mathrm{Albemarle}$. 


\subsection{Catalyst Activation}

Prior to the attrition studies, the calcined $\mathrm{Fe}-\mathrm{Cu}-\mathrm{K} /$ spent $\mathrm{FCC}$ catalysts were activated in presence of $\mathrm{CO}$ at ambient pressure and at a temperature of $553 \mathrm{~K}$. The catalysts were first heated in a quartz reactor to a temperature of $553 \mathrm{~K}$ at $2 \mathrm{~K} \mathrm{~min}^{-1}$ in presence of helium. After attaining the temperature $553 \mathrm{~K}$, the gas flow was changed to $50 \% \mathrm{CO}$, balance helium at a total flow rate of $600 \mathrm{cc} \mathrm{min}^{-1} \mathrm{gcat}^{-1}$ for $24 \mathrm{~h}$. After activation, the reactor was cooled down to room temperature under helium flow and then the catalysts were passivated by passing $1 \% \mathrm{O}_{2}$, balance helium for $4 \mathrm{~h}$. After passivation, the catalyst was unloaded from the reactor carefully and stored in a sealed container. These catalysts were used for attrition tests.

\subsection{Catalyst Characterization}

BET S.A., pore volume and pore size of the calcined, activated catalysts and spent FCC supports were measured using autosorb (AS-1, M/S Quantachrome) by adsorbing $\mathrm{N}_{2}$ at its liquefaction temperature $77 \mathrm{~K}$. These samples were degassed at $423 \mathrm{~K}$ for $2 \mathrm{~h}$ prior to $\mathrm{N}_{2}$ adsorption-desorption process. ICP-MS analysis was used to measure the metal composition of the catalysts. Powder X-ray diffraction analysis of the calcined catalysts was done by using $\mathrm{Cu}$ $\mathrm{K}_{\alpha}$ radiation and $\mathrm{Co}-\mathrm{K}_{\alpha}$ radiation was used for $\mathrm{CO}$ activated catalysts. These samples were scanned in the $2 \theta$ range of $10-80^{\circ}$ at $1^{\circ} \mathrm{min}^{-1}$ of scan speed. These patterns were recorded on Siemens D5000 automated powder X-ray diffractometer. Phase identification was done by using ICDD database. $\mathrm{H}_{2}$-TPR experiments were carried out in a fixed bed micro reactor system. 50 $\mathrm{mg}$ of the sample was placed in a $6 \mathrm{~mm}$ i. d. reactor tube and reduced in a $10 \% \mathrm{H}_{2} / \mathrm{Ar}$ mixture while the temperature was linearly ramped from $323 \mathrm{~K}$ to $1073 \mathrm{~K}$ at $5 \mathrm{~K} \mathrm{~min}^{-1}$. A thermal conductivity detector (TCD) was used to monitor $\mathrm{H}_{2}$ consumption as a function of temperature. 
The Fe K-edge XANES scans were taken at the J. Bennett Johnston Sr., Center for Advanced Materials and Devices (CAMD), Louisiana State University, which operates its storage ring with an electron energy of $1.3 \mathrm{GeV}$ and a current typically between 90 and $190 \mathrm{~mA}$. The monochromator crystals used were Ge (220) and the resolution at the energies studied is $\sim 2$

eV. The Fe standards used were $\mathrm{Fe}_{2} \mathrm{O}_{3}\left(99.85+\%\right.$ metals basis Alfa Aesar $\left.{ }^{\circledR}\right), \mathrm{Fe}_{3} \mathrm{O}_{4}$ $\left(99.95 \%\right.$ metals basis Alfa Aesar $\left.^{\circledR}\right), \mathrm{FeO}\left(99.5 \%\right.$ metals basis Alfa Aesar $\left.^{\circledR}\right)$, and a $7.5 \mu \mathrm{m}$ thick $\alpha$-Fe foil positioned after the transmission chamber for calibration purposes. A $\theta-\mathrm{Fe}_{3} \mathrm{C}$ standard was synthesized using a $\mathrm{CO}$ TPR of $\mathrm{Fe}_{2} \mathrm{O}_{3}$, using a similar procedure to the literature [26]. Athena as well as IFEFFIT software were used in the data analysis [27].

\subsection{Attrition tests}

Catalyst attrition testing was performed by Sud-Chemie in a jet cup system based on ASTM design as described previously [28]. In a typical attrition test, $5 \mathrm{~g}$ of the activated catalyst sample was charged in to the sample cup and then attached to the settling chamber. After all joints were sealed, wet air was introduced into the sample at a controlled flow rate of $211 \mathrm{~min}^{-1}$ and at a pressure of $3.5 \mathrm{bar}$. After $1 \mathrm{~h}$ time-on-stream (TOS), the air flow was stopped and the weight of fines collected by the downstream filter was determined and "weight percentage of fines lost" calculated.

\subsection{Activity studies}

The F-T reaction was carried out in a continuous flow fixed bed high pressure reactor. In a typical experiment, $1 \mathrm{~g}$ of the catalyst was loaded in to the reactor and was activated in presence of $50 \% \mathrm{CO}$ balance $\mathrm{N}_{2}$ at $553 \mathrm{~K}$, as previously described. After activation, the reactor was flushed with $\mathrm{N}_{2}$ flow at $100 \mathrm{SCCM}$ for $1 \mathrm{~h}$. After flushing with $\mathrm{N}_{2}$, the reaction was carried out at $573 \mathrm{~K}, \mathrm{H}_{2}: \mathrm{CO}$ of 0.67 and at a pressure equals to $1.38 \mathrm{MPa}$. The reaction mixture was 
diluted with $\mathrm{N}_{2}$ at a ratio of 1:5 ( $\mathrm{N}_{2}$ :syngas) and total GHSV equals to $3600 \mathrm{~h}^{-1}$. The catalyst was diluted with $5 \mathrm{~g}$ quartz sand prior to loading in to the reactor to minimize the hotspots due to the exothermic nature of the reaction. The hot trap and reactor vent lines were maintained at $423 \mathrm{~K}$ and cold trap was maintained at $275 \mathrm{~K}$. The gaseous products were analyzed in-situ using GC equipped with FID and TCD. Liquid and wax products were collected periodically and their

${ }^{\mathrm{c}}$ measured at $\mathrm{P} / \mathrm{P}_{0}=0.99,{ }^{\mathrm{d}}$ measured using t-plot method

weights were measured by a mass balance and were analyzed by using GC. The CO conversion $\mathrm{k} / /$ and product selectivities are calculated as follows:

$\%$ conversion of $\mathrm{CO}=\left[\mathrm{n}(\mathrm{CO})_{\text {in }}-\mathrm{n}(\mathrm{CO})_{\text {out }} / \mathrm{n}(\mathrm{CO})_{\text {in }}\right] \mathrm{X} 100$

$\%$ 'C' selectivity of product $=[$ no. of moles of product formed $\mathrm{X}$ no. of $\mathrm{C}$ atoms presen $/$ $=$ no. of moles of $\mathrm{CO}$ consumed] X 100

Table 1. Textural property of the catalysts

\begin{tabular}{lcccc}
\hline Catalyst & $\begin{array}{c}\text { BET S.A. } \\
\left(\mathrm{m}^{2} \mathrm{~g}^{-1}\right)\end{array}$ & $\begin{array}{c}\text { Total pore } \\
\text { volume }\left(\mathrm{cc}^{-1}\right)\end{array}$ & $\begin{array}{c}\text { Pore size } \\
(\mathrm{nm})\end{array}$ & $\begin{array}{c}\text { micropore area }^{\mathbf{d}} \\
\left(\mathrm{m}^{2} \mathrm{~g}^{-1}\right)\end{array}$ \\
\hline Albemarle & 148 & 0.15 & 4.07 & 101.4 \\
Engelhard & 101 & 0.1 & 4.3 & 56.9 \\
${ }^{\mathrm{a}} \mathrm{Fe}-\mathrm{Cu}-\mathrm{K} /$ Albemarle & 31 & 0.07 & 9.4 & 3.2 \\
${ }^{\mathrm{a}} \mathrm{Fe}-\mathrm{Cu}-\mathrm{K} /$ Engelhard & 27 & 0.06 & 9.9 & 2.0 \\
${ }^{\mathrm{b}} \mathrm{Fe}-\mathrm{Cu}-\mathrm{K} /$ Albemarle & 38 & 0.08 & 8.7 & 4.2 \\
${ }^{\mathrm{b}} \mathrm{Fe}-\mathrm{Cu}-\mathrm{K} /$ Engelhard & 37 & 0.09 & 9.4 & 3.7 \\
\hline
\end{tabular}

${ }^{\mathrm{a}}$ calcined catalysts, ${ }^{\mathrm{b}}$ catalysts activated in presence of $\mathrm{CO}$

${ }^{\mathrm{c}}$ measured at $\mathrm{P} / \mathrm{P}_{0}=0.99,{ }^{\mathrm{d}}$ measured using t-plot method 


\subsection{Results and discussions}

\subsection{Textural properties and metal analysis}

Table- 1 shows the textural properties of spent FCC supports, calcined and CO activated Fe$\mathrm{Cu}-\mathrm{K} /$ spent FCC catalysts. Pore size distributions of spent FCC supports as well as calcined and carbided catalysts were presented in figure-1A and B. The BET surface areas of the supports were found

Table 2 Metal composition from ICP-MS analysis

\begin{tabular}{|c|c|c|c|c|c|c|c|c|}
\hline \multirow[t]{2}{*}{ Catalyst } & \multicolumn{8}{|c|}{ Metal composition (parts by wt) } \\
\hline & $\mathbf{F e}$ & $\mathbf{C u}$ & $\mathbf{K}$ & Si & Al & $\mathbf{T i}$ & $\mathbf{V}$ & $\mathbf{Z} \mathbf{l}$ \\
\hline \multicolumn{9}{|l|}{$\begin{array}{ll}\mathrm{Ni} & \mathrm{Ca}\end{array}$} \\
\hline Engelhard $^{\mathrm{a}}$ & 0.58 & - & - & 23.9 & 20.7 & 0.7 & 0.08 & 0.02 \\
\hline \multicolumn{9}{|l|}{$\begin{array}{ll}0.05 & 0.02\end{array}$} \\
\hline Albemarle $^{a}$ & 0.54 & - & - & 21.9 & 22.1 & 0.7 & 0.08 & 0.01 \\
\hline \multicolumn{9}{|l|}{$0.02 \quad 0.04$} \\
\hline $\mathrm{Fe}-\mathrm{Cu}-\mathrm{K} /$ Engelhard $^{\mathrm{b}}$ & 45.1 & 1.95 & 1.3 & 5.5 & 5.8 & 0.22 & $<0.05$ & 0.001 \\
\hline $0.01 \quad 0.02$ & & & & & & & & \\
\hline $\mathrm{Fe}-\mathrm{Cu}-\mathrm{K} / \mathrm{Albemarle}{ }^{\mathrm{b}}$ & 44.3 & 1.92 & 1.3 & 6.3 & 5.5 & 0.23 & $<0.05$ & 0.002 \\
\hline $0.015 \quad 0.02$ & & & & & & & & \\
\hline
\end{tabular}

* measured from ICP-MS analysis, ${ }^{\mathrm{a}}$ spent FCC supports, ${ }^{\mathrm{b}}$ calcined catalysts

to be $101 \mathrm{~m}^{2} \mathrm{~g}^{-1}$ and $158 \mathrm{~m}^{2} \mathrm{~g}^{-1}$ for Engelhard and Albemarle materials respectively. The calcined and activated catalysts have far less surface areas compared to the spent FCC supports. This can be attributed to the addition of $\mathrm{Fe}, \mathrm{Cu}$ and $\mathrm{K}$ over spent $\mathrm{FCC}$ supports which, in turn leads to blocking the pores of spent FCC support. The reduction in the pore size distribution from spent FCC support to calcined and activated catalysts is seen in both cases (Figure1\&Table-1). The CO activation of the calcined catalysts leads to a small increase in surface area. The change in pore volume was negligible. These findings are in good agreement with Zhao et al. [29]. The metal composition of the catalysts was shown in Table-2. An ICP-MS analysis 
(Table-2) show Si to Al ratios of the supports are 0.99 and 1.16 for Engelhard and Albemarle supports respectively and remains constant after loading of $\mathrm{Fe}, \mathrm{Cu}$ and $\mathrm{K}$ metals. Also metal analysis shows that both the spent FCC supports were poisoned with heavy metals such as Ti, V, $\mathrm{Ni}, \mathrm{Zr}$ and $\mathrm{Ca}$ in trace amounts. It is known that during the process FCC catalysts are contaminated with heavy metals $[20,22]$. The compositions of both the calcined F-T catalysts $(100 \mathrm{Fe} / 4.3 \mathrm{Cu} / 2.8 \mathrm{~K} / 25$ Engelhard \& $100 \mathrm{Fe} / 4.3 \mathrm{Cu} / 2.9 \mathrm{~K} / 26.6$ Albemarle) are found to be close to the target Ruhrchemie catalyst composition. The carbon analysis shows both the spent FCC supports contain $0.12 \mathrm{wt} \% \mathrm{C}$, while calcined catalysts show $0.18 \mathrm{wt} \% \mathrm{C}$ (Albemarle supported) and $0.2 \mathrm{wt} \% \mathrm{C}$ (Engelhard supported). The increase in $\mathrm{C}$ content may be due to $\mathrm{KHCO}_{3}$ that does not decompose during calcinations.

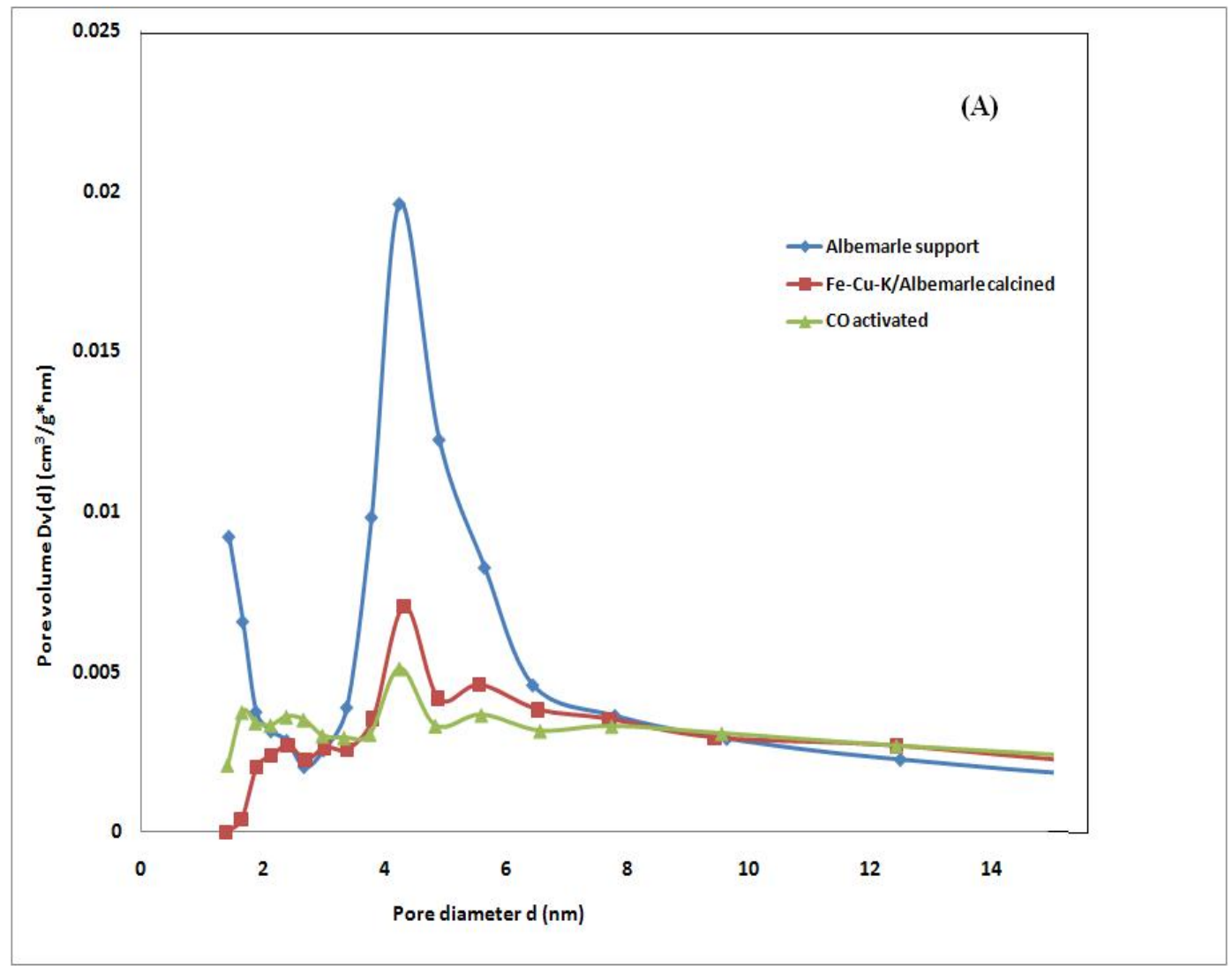




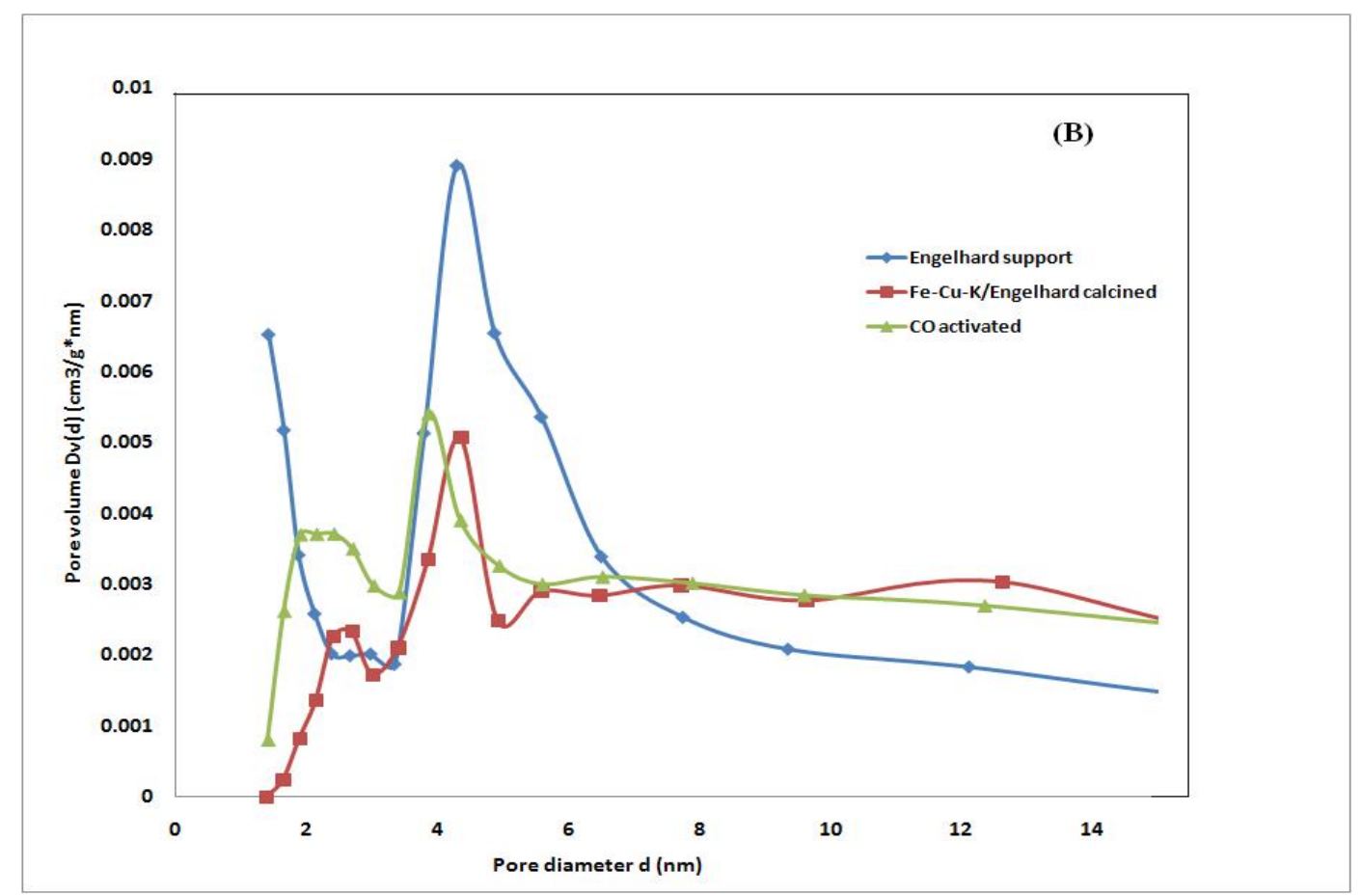

Figure 1. Pore size distribution curves of spent FCC Support, calcined and activated Fe-Cu- K/ spent FCC catalysts.

\subsection{TPR results}

The $\mathrm{H}_{2}$-TPR profiles of the $\mathrm{Cu}, \mathrm{K}$ promoted Fe loaded over spent $\mathrm{FCC}$ supports and spent FCC supports alone are presented in Figure-2. Spent FCC supports alone without any active metal show no reduction peak. The reduction profiles of calcined $\mathrm{Fe}-\mathrm{Cu}-\mathrm{K} /$ spent $\mathrm{FCC}$ catalysts shows two main stages of reduction at about 573-593 $\mathrm{K}$ and 853-893 $\mathrm{K}$. The low temperature peak corresponds to the reduction of $\mathrm{Fe}_{2} \mathrm{O}_{3}$ to $\mathrm{Fe}_{3} \mathrm{O}_{4}$ and $\mathrm{CuO}$ to $\mathrm{Cu}$ [30]. The presence of $\mathrm{Cu}$ in the catalysts shifts the reduction of $\mathrm{Fe}_{2} \mathrm{O}_{3}$ to $\mathrm{Fe}_{3} \mathrm{O}_{4}$ towards lower temperatures. $\mathrm{Cu}$ crystallites nucleate during reduction of $\mathrm{CuO}$ and provide $\mathrm{H}_{2}$ dissociation sites that lead to reactive hydrogen species capable to reduce Fe oxides at a relatively low temperature [30]. In the first stage, Albemarle-spent FCC supported catalyst shows two distinct reduction peaks centered at $493 \mathrm{~K}$ and $593 \mathrm{~K}$. In case of Engelhard-spent FCC supported catalyst shows a shoulder at $473 \mathrm{~K}$ and 
another peak at $573 \mathrm{~K}$. In both the cases, the first peak corresponds to the reduction of $\mathrm{CuO}$ to $\mathrm{Cu}$ and the second corresponds to the reduction of $\mathrm{Fe}_{2} \mathrm{O}_{3}$ to $\mathrm{Fe}_{3} \mathrm{O}_{4}$ [31]. The second stage of the reduction shown at $853-893 \mathrm{~K}$ corresponds to the reduction of $\mathrm{Fe}_{3} \mathrm{O}_{4}$ to metallic iron. Engelhard (spent FCC) supported catalyst shows relatively lower reduction temperatures at all stages by approximately $20 \mathrm{~K}$, which can be attributed to interactions between $\mathrm{Cu}$ and $\mathrm{Fe}$.

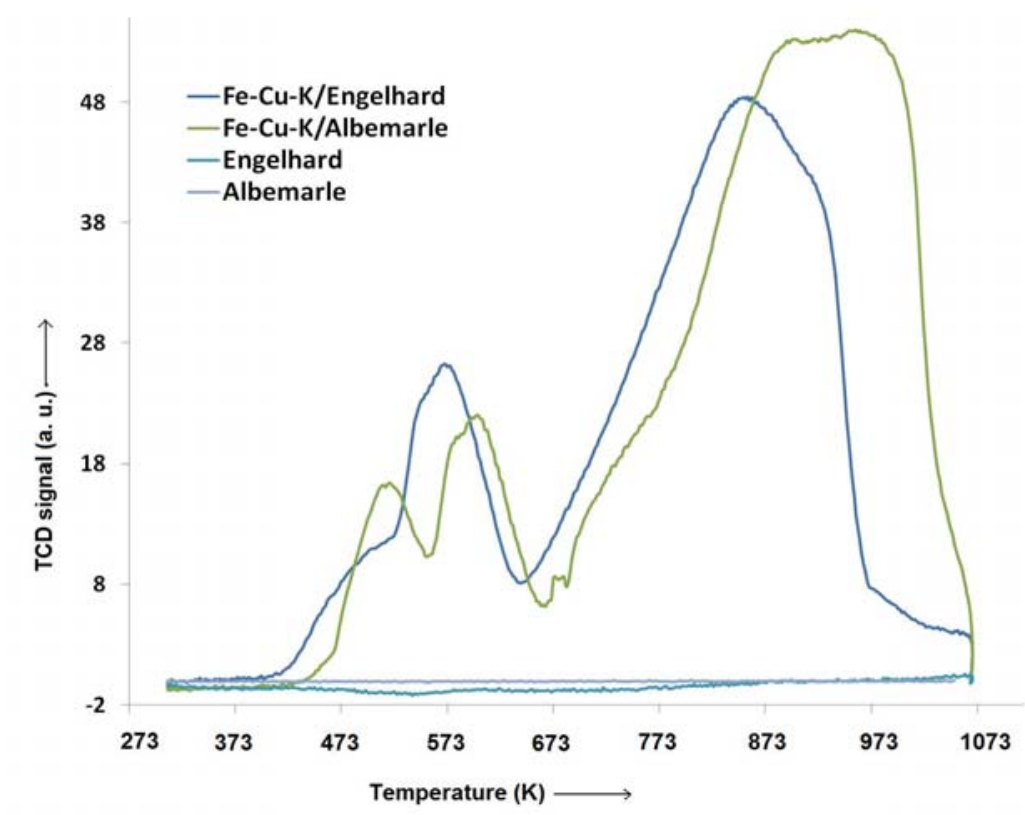

Figure 2. $\mathrm{H}_{2}$-TPR profiles of $\mathrm{Cu}, \mathrm{K}$ promoted $\mathrm{Fe}$ supported over spent $\mathrm{FCC}$ catalysts and pure spent FCC supports.

\subsection{XRD results}

Powder X-ray diffraction patterns of both calcined and $\mathrm{CO}$ pretreated catalysts are presented in Figure-3. The patterns of the calcined Fe-Cu-K/Spent FCC catalysts show strong peaks at $2 \theta$ values of $24.2^{\circ}, 33.2^{\circ}, 35.7^{\circ}, 40.8^{\circ}, 49.6^{\circ}, 54.2^{\circ}$ and $64.1^{\circ}$, which represent catalysts comprised entirely of $\alpha-\mathrm{Fe}_{2} \mathrm{O}_{3}$ (rhombohedral hematite) phase [32]. The catalysts pretreated in 
presence of $\mathrm{CO}$ at $553 \mathrm{~K}$ exhibits the peaks for $\mathrm{Fe}_{3} \mathrm{O}_{4}$ (magnetite) and $\chi-\mathrm{Fe}_{5} \mathrm{C}_{2}$ (Hägg carbide). Both magnetite and Fe-carbide have a peak at $2 \theta$ value of $43.6^{\circ}$. Several researchers reported the phase of the activated catalysts will depend strongly on the pretreatment conditions employed $[12,29]$. Kalakkad et al. reported that the $100 \%$ intensity peak for magnetite occurs at $35.6^{\circ}$ and the ratio of the $35.5^{\circ}$ to and the $43^{\circ}$ peak areas should be around 3.33 if only magnetite was present in the sample [12]. The ratio would decrease if there was an Fe-carbide phase present along with magnetite. Using this approach, they report that the catalyst sample exposed to $\mathrm{CO}$ at $543 \mathrm{~K}$ contained both magnetite and Fe-carbide phases. Zhao et al. reported that catalysts carburized under higher flow rates $\left(375 \mathrm{~cm}^{3} \mathrm{~min}^{-1}\right)$ of $\mathrm{CO}$ mainly consists of magnetite and $\chi$ carbide $\left(\mathrm{Fe}_{5} \mathrm{C}_{2}\right)$ and a syngas activated catalyst consisted of magnetite and $\dot{\varepsilon}$-carbide [29] .

\subsection{XANES results}

The Fe K-edge XANES spectra for the standards, as well as the fresh calcined and activated Albemarle and Engelhard catalysts are presented in Figure-4. As expected, the XANES spectra of the fresh calcined catalysts were in good agreement with the $\mathrm{Fe}_{2} \mathrm{O}_{3}$ standard. After $\mathrm{CO}$ activation (conditions previously discussed) the Fe in the catalyst was found to be a mixture of the $\mathrm{Fe}_{3} \mathrm{O}_{4}$ and $\mathrm{Fe}_{\mathrm{x}} \mathrm{C}$ phases. A Principal Component Analysis [33] of the Albemarle and Engelhard XANES spectra confirmed the presence of $\theta-\mathrm{Fe}_{3} \mathrm{C}, \mathrm{Fe}_{2} \mathrm{O}_{3}, \mathrm{Fe}_{3} \mathrm{O}_{4}$ and excluded $\alpha-\mathrm{Fe}$, $\mathrm{FeO}$, which is consistent with the literature for a $\mathrm{CO}$ pretreated Fe-based FT catalyst [26, 34-36]. An assumption made in the least squares fitting was that the XANES contribution from the iron carbide $\left(\mathrm{Fe}_{\mathrm{x}} \mathrm{C}\right)$ would be close agreement to the $\theta-\mathrm{Fe}_{3} \mathrm{C}$ standard, which was also assumed in previous studies $[26,34,36]$. The least squares fitting results are in Table-3. The results of the fit were in good agreement with the XRD data, suggesting that the Fe in the fresh calcined catalyst 
is present as $\mathrm{Fe}_{2} \mathrm{O}_{3}$. In addition, the activated catalyst is a combination of $\mathrm{Fe}_{\mathrm{x}} \mathrm{C}$ and $\mathrm{Fe}_{3} \mathrm{O}_{4}$, which is also consistent with the XRD analysis; it was observed that after $\mathrm{CO}$ activation that the Engelhard-spent FCC supported catalyst was slightly more carburized than the Albemarle-spent FCC supported catalyst. 

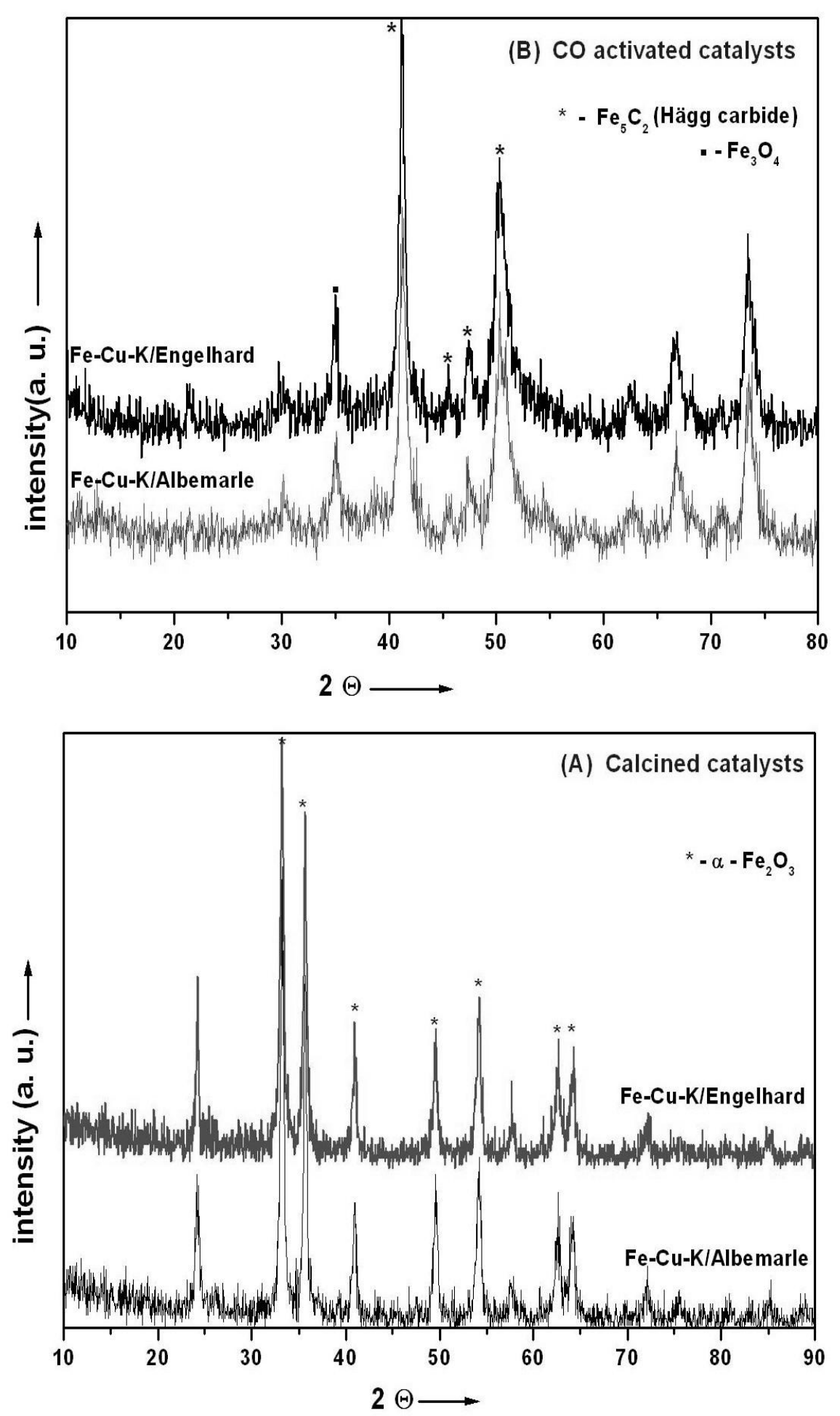

Figure 3. Powder X-ray diffraction patterns of (A) calcined catalysts and (B) CO activated catalysts. 


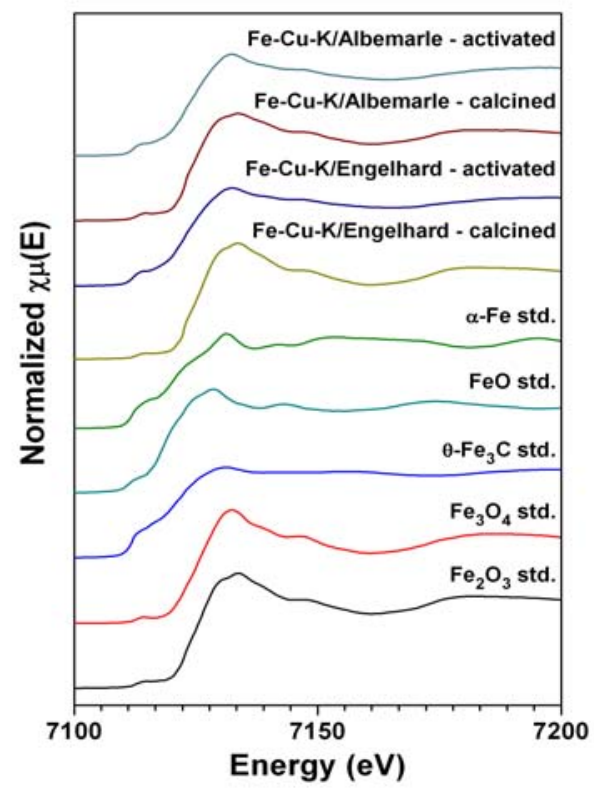

Figure 4. Normalized Fe K-edge XANES of Fe standards, calcined and activated Fe-Cu k/spent FCC catalysts.

\section{Table 3}

Least squares fitting results for calcined and activated $\mathrm{Fe}-\mathrm{Cu}-\mathrm{K} /$ spent FCC catalysts.

\begin{tabular}{ccccc}
\hline Catalyst & Condition & $\mathbf{F e}_{\mathbf{2}} \mathbf{O}_{\mathbf{3}}(\%)$ & $\mathbf{F e}_{\mathbf{3}} \mathbf{O}_{\mathbf{4}}(\mathbf{\%})$ & $\mathbf{F e C}_{\mathbf{x}}(\mathbf{\%})$ \\
\hline Fe-Cu-K/Engelhard & calcined & 100 & 0 & 0 \\
& activated & 0 & $52.3 \pm 1.6$ & $47.7 \pm 1.6$ \\
Fe-Cu-K/Albemarle & calcined & 100 & 0 & 0 \\
& activated & 0 & $63.7 \pm 1.1$ & $36.3 \pm 1.1$ \\
& & & &
\end{tabular}

\subsection{Attrition results}

Attrition of catalysts as determined by jet cup measurement is given in Table-4. Both the spent FCC supports shows negligible attrition. The addition of $\mathrm{Fe}, \mathrm{Cu}$ and $\mathrm{K}$ to the spent $\mathrm{FCC}$ supports leads to increase in the lost of fines (wt\%), likely due to breakup of Fe-carbide into smaller particles. These iron catalysts show appreciable attrition resistance in comparison of literature studies, in which the attrition tests were conducted under similar conditions [29, 37]. Zhao et al. synthesized the spray-dried, $\mathrm{Cu}$ - and $\mathrm{K}$ - promoted Fe catalyst containing $9.1 \mathrm{wt} \%$ of silica binder 
[29]. This catalyst was tested for attrition by jet cup method after pretreatment with $\mathrm{CO}$ at $553 \mathrm{~K}$ and $\mathrm{wt} \%$ of fines lost was found to be 7.5-7.7, slightly lower than the present results (8.2-9.3 wt $\%$ ). Similar results were also observed in a related study by Zhao et al. [37]. The attrition test conditions employed in the present study are more severe than employed by Zhao et al. [29, 37].

\subsection{F-T Activity results}

F-T synthesis performances of the catalysts were measured in a fixed bed reactor at $T=573 \mathrm{~K}, P$ $=1.38 \mathrm{MPa}, \mathrm{H}_{2} / \mathrm{CO}=0.67$ and GHSV of $3600 \mathrm{~h}^{-1}$. The activities, stabilities and selectivities were tested over a period of $24 \mathrm{~h}$. The effect of reaction time on $\mathrm{CO}$ and $\mathrm{H}_{2}$ conversion over both the $\mathrm{Fe}-\mathrm{Cu}-\mathrm{K} /$ spent FCC catalysts over time on stream are presented in Figure-5.

Table 4 Jet cup attrition test results

\begin{tabular}{lc}
\hline Catalyst & Fines lost $_{(\mathbf{w t} \%)^{\mathbf{a}, \mathbf{b}}}$ \\
\hline Engelhard & 1.2 \\
Albemarle & 0.8 \\
Fe-Cu-K/Engelhard $^{\mathrm{c}}$ & 8.2 \\
Fe-Cu-K/Albemarle $^{\mathrm{c}}$ & 9.3 \\
\hline
\end{tabular}

\footnotetext{
${ }^{\text {a }}$ Weight precentage of fines $=$

(weight of fines collected/weight of total catalyst recovered) X 100

${ }^{\mathrm{b}}$ Error: $\pm 10 \%$ of the value measured

${ }^{\mathrm{c}}$ Catalysts activated in presence of $\mathrm{CO}$ at $553 \mathrm{~K}$
} 


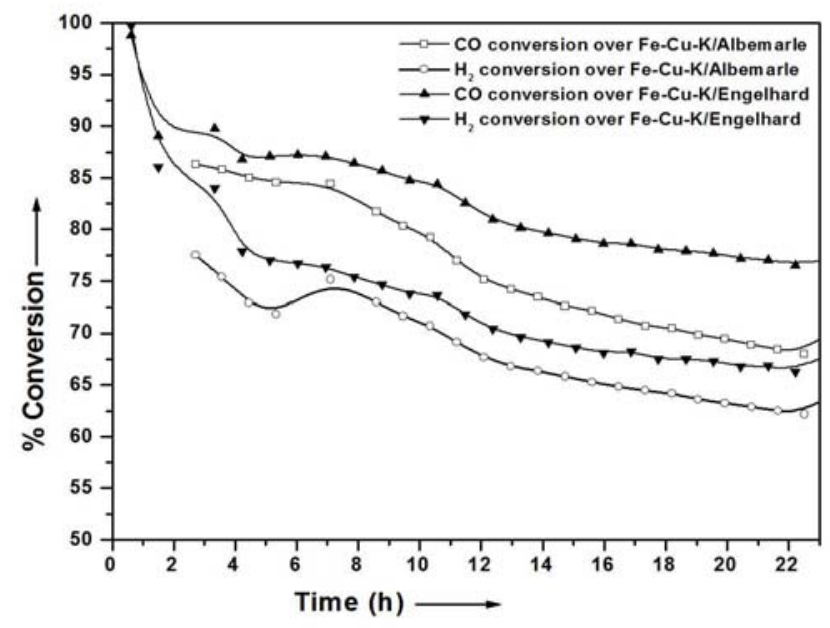

Figure 5. $\mathrm{CO}$ and $\mathrm{H}_{2}$ conversion as a function of time on stream.

The initial conversion of $\mathrm{CO}$ is similar on both catalysts $(86.3 \%$ over Albemarle spent FCC and 89\% over Engelhard spent FCC). As the reaction proceeds, the conversion drops down continuously over Albemarle-spent FCC supported catalyst and reaches down to $68 \%$ at $24 \mathrm{~h}$. For the catalyst supported over Engelhard-spent FCC, CO conversion decreases to 81\% after 12 $\mathrm{h}$, and then less rapidly thereafter. The loss of activity with time on stream can be the result of one or more of following reasons: (i) deposition of inactive carbonaceous layer, (ii) sintering of metal particles, (iii) phase transformations in the FT component and (iv) coking of zeolitic component [23,38]. Deposition of inactive carbonaceous compounds through Boudouard reaction is the most common way of Fe catalysts deactivation as shown in Eqs.(3) and (4) [38].

$\mathrm{C} *+2 \mathrm{CO} \longrightarrow \mathrm{C}-\mathrm{C} *+\mathrm{CO}_{2}$

$\mathrm{C} *+\mathrm{CO}+\mathrm{H}_{2} \longrightarrow \mathrm{C}-\mathrm{C} *+\mathrm{H}_{2} \mathrm{O}$

Pour et al. studied the HZSM-5 zeolite supported Fe catalysts and found that the CO conversion decreased from $97 \%$ to $85 \%$ at $200 \mathrm{~h}$ and to $70 \%$ at $1400 \mathrm{~h}$ on stream. They attributed the loss of activity to coking of the zeolite component, migration of the iron catalyst alkali promoters under synthesis conditions and dealumination of zeolites crystals caused by the presence of water[23]. 
The catalyst reported in the present study use spent FCC material as supports, which contain zeolites that might cause the catalyst deactivation. The Engelhard-spent FCC supported catalyst is significantly more active than the Albemarle catalyst. The same trend is observed in case of $\mathrm{H}_{2}$ conversion. These spent FCC supported Fe catalysts show high activity in comparison with the $\mathrm{Fe}$ catalysts supported over conventional supports like $\mathrm{SiO}_{2}$ and $\mathrm{Al}_{2} \mathrm{O}_{3}$ prepared in an analogous way $[39,40\}$. Bukur et al. studied $\mathrm{SiO}_{2}$ and $\mathrm{Al}_{2} \mathrm{O}_{3}$ supported $\mathrm{Fe}$ catalysts with a composition of $100 \mathrm{Fe} / 5 \mathrm{Cu} / 6 \mathrm{~K} / 139 \mathrm{SiO}_{2}$ and $100 \mathrm{Fe} / 5 \mathrm{Cu} / 9 \mathrm{~K} / 139 \mathrm{Al}_{2} \mathrm{O}_{3}$ for $\mathrm{F}-\mathrm{t}$ synthesis in stirred tank slurry reactor at $533 \mathrm{~K} / 1.5 \mathrm{MPa}$ and $\mathrm{H}_{2} / \mathrm{CO}=0.67[39]$. They found that $\mathrm{Al}_{2} \mathrm{O}_{3}$ supported catalyst showed maximum syngas conversion of $45 \%$ at $20 \mathrm{~h}$ on stream and then started to deactivate (35\% conversion at $100 \mathrm{~h}$ ) and the activity on $\mathrm{SiO}_{2}$ supported catalyst shows $67 \%$ conversion at $20 \mathrm{~h}$ on stream to $60 \%$ at $100 \mathrm{~h}$ on stream. O'Brien et al. evaluated four different supported catalysts $100 \mathrm{Fe} / 6 \mathrm{Cu} / 8.1 \mathrm{~K} / 250-260$ support material $\left(\mathrm{SiO}_{2}, \mathrm{MgO} \mathrm{SiO}_{2}, \mathrm{Al}_{2} \mathrm{O}_{3}\right.$ and $\mathrm{MgAl}_{2} \mathrm{O}_{4}$ in a slurry reactor at $523 \mathrm{~K}, 1.31 \mathrm{MPa}$ and $\mathrm{H}_{2} / \mathrm{CO}=0.7[40]$. The maximum $\mathrm{CO}$ conversion reported at $50 \mathrm{~h}$ on stream was $50 \%$ over $\mathrm{MgAl}_{2} \mathrm{O}_{4}$ supported catalysts. The $\mathrm{Fe}$ catalyst supported over Engelhard-spent FCC reported in the present study shows CO conversion of $81 \%$ ( Table 5), which is higher than in comparison with the Fe F-T catalysts prepared by conventional coprecipitation and having similar catalyst composition[39,41]. O'Brien et al. reported $\mathrm{CO}$ conversions of $70 \%$ with the catalyst composition of $100 \mathrm{Fe} / 5 \mathrm{Cu} / 4.2 \mathrm{~K} / 24 \mathrm{SiO}_{2}$ and Hou et al. reported $48.5 \%$ of $\mathrm{CO}$ conversions over catalysts with the composition $100 \mathrm{Fe} / 5 \mathrm{Cu} / 4.2 \mathrm{~K} / 15 \mathrm{SiO}_{2}$. Although there is slight difference in reaction conditions, the high activity of the catalysts reported here can be attributed to the difference in the support materials used and catalyst preparation method. This shows an apparent advantage of using spent FCC material as a support for Fe F-T catalysts. Table 5 shows the pseudo-steady state F-T activity of 
the catalysts. The chain growth probability $(\alpha)$ values for the two catalysts are equal within experimental error,0.55-0.54 (fig. 6). In this study the linear region $\left(\mathrm{C}_{3}-\mathrm{C}_{8}\right)$ of the ASF plot was used $\left[\ln \left(\mathrm{w}_{\mathrm{n}} / \mathrm{n}\right)\right.$ vs. $\left.\mathrm{n}\right]$ to calculate the $\alpha$ value. Time on stream studies show that methane and $\mathrm{CO}_{2}$ selectivities increase initially up to $5 \mathrm{~h}$ of reaction time and no significant changes were observed at longer times (fig.7). At steady state, the $\mathrm{CH}_{4}$ and $\mathrm{CO}_{2}$ selectivities are found to be $5.2 \%$ and $54.5 \%$ respectively over Albermarle-spent FCC supported catalyst and $3.9 \%$ and $49.3 \%$ respectively over Engelhard - spent FCC supported catalyst. The high $\mathrm{CO}_{2}$ selectivities can be attributed to water-gas shift reaction. Luo et al. also found a similar $\mathrm{CO}_{2}$ selectivity (45\%) when Fe catalysts activated under $\mathrm{CO}$ at $543 \mathrm{~K}$ [42].

\section{Table 5 F-T activity results}

\begin{tabular}{|c|c|c|}
\hline F-T results ${ }^{a}$ & Fe-Cu-K/Engelhard & Fe-Cu-K/Albemarle \\
\hline$\% \mathrm{CO}$ conversion ${ }^{\mathrm{b}}$ & 81.0 & 69.5 \\
\hline$\%$ selectivity $(\% \mathrm{C})$ & & \\
\hline $\mathrm{CO}_{2}$ & 49.3 & 54.5 \\
\hline $\mathrm{CH}_{4}$ & 3.9 & 5.2 \\
\hline $\mathrm{C}_{2}-\mathrm{C}_{4} \mathrm{HC}^{\prime} \mathrm{s}$ & 9.4 & 8.5 \\
\hline $\mathrm{C}_{5}+\mathrm{HC}^{\prime} \mathrm{s}$ & 18.3 & 12.0 \\
\hline oxygenates & 1.6 & 2.1 \\
\hline $\begin{array}{c}\mathbf{C}_{2}{ }^{=}-\mathbf{C}_{4}{ }^{=} / \mathbf{C}_{2}-\mathbf{C}_{4} \\
\text { (olefins/paraffins) }\end{array}$ & 4.0 & 3.2 \\
\hline $\operatorname{ASF}(\alpha)$ & 0.55 & 0.54 \\
\hline
\end{tabular}




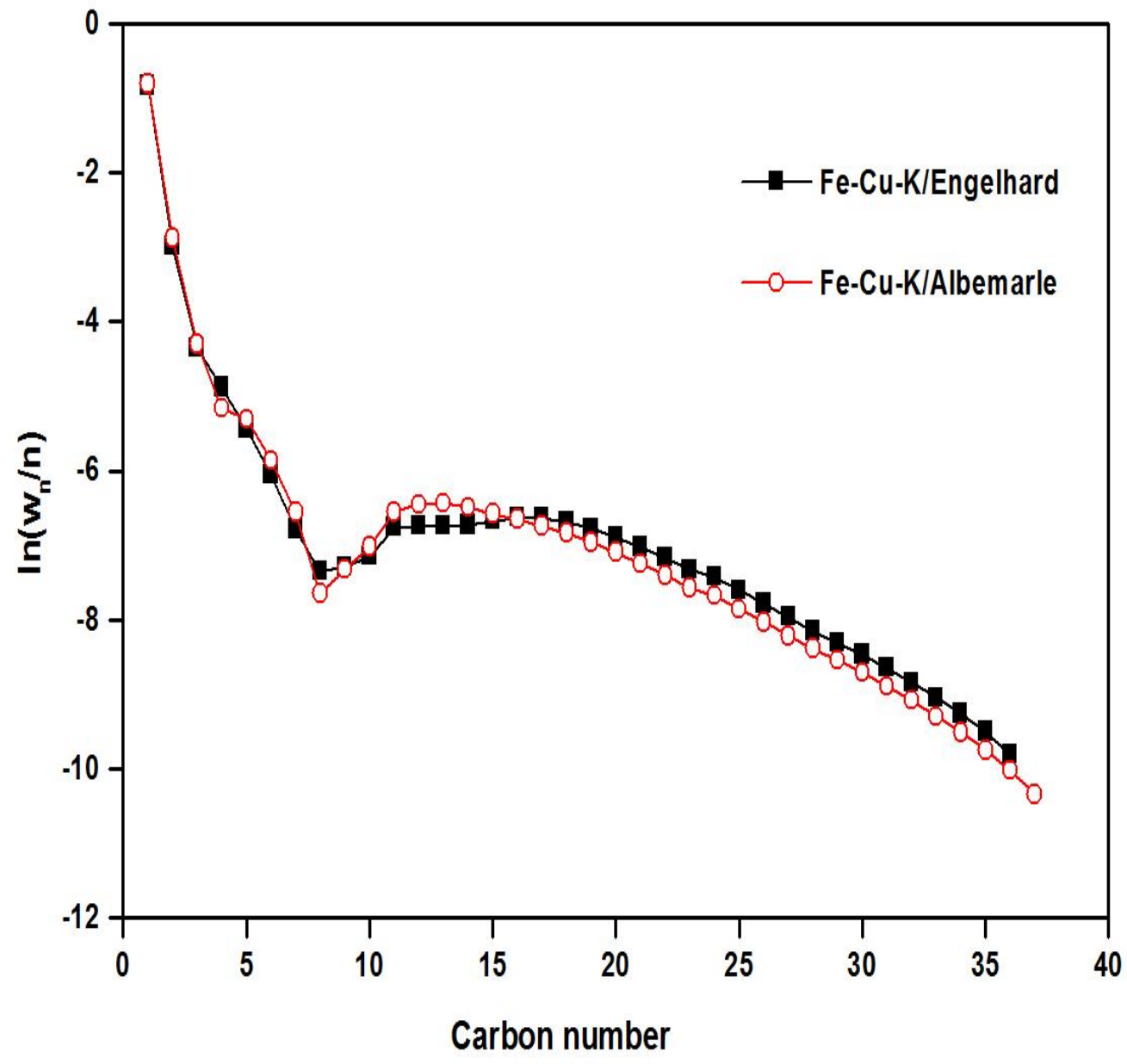

Fig. 6 Anderson- Schulz- Flory plot of chain growth. 

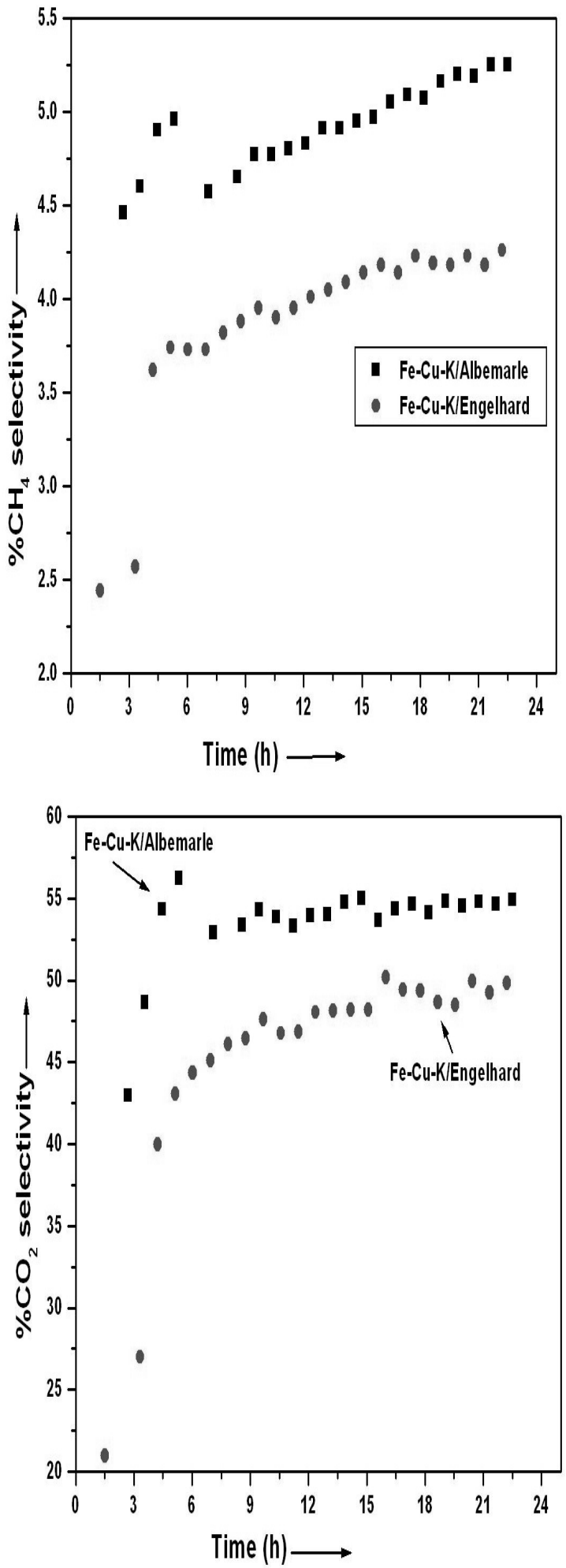

Fig. 7 Selectivity of $\mathrm{CO}_{2}$ and $\mathrm{CH}_{4}$ with time on stream. 
$\mathrm{C}_{2}-\mathrm{C}_{4}$ hydrocarbons yield was $8.5 \%$ and $9.4 \%$ over Albemarle and Engelhard-spent FCC supported catalysts respectively at steady state (fig. 8). Albemarle-spent FCC supported catalyst shows lower $\mathrm{C}_{2}-\mathrm{C}_{4}$ olefins-to-paraffins ratio than compared to Engelhard-spent FCC supported catalyst. The $\mathrm{C}_{5}+$ hydrocarbon selectivity was $12 \%$ and $18.5 \%$ with the oxygenates selectivity of $1.6 \%$ and $2.1 \%$ over Albemarle and Engelhard-spent FCC supported catalysts respectively. Table- 6 shows the oxygenate product distribution in the aqueous product. Engelhard-spent FCC supported catalyst shows predominant formation of ethanol (41.9 ' $\mathrm{C}$ ' mol \%) among all the oxygenates, which is much higher than ethanol produced on Albemarle-spent FCC supported catalyst ( $4.8^{\circ} \mathrm{C}$ ' $\left.\mathrm{mol} \%\right)$.

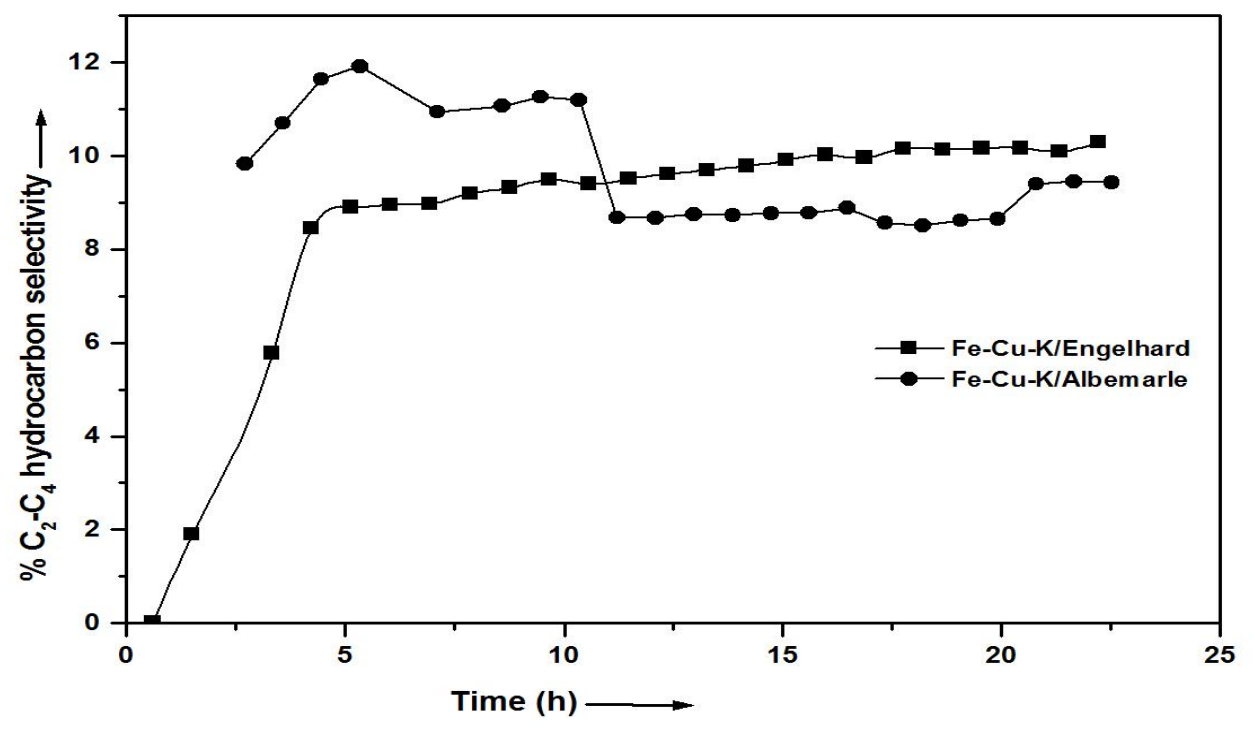

Fig 8. Selectivity of $\mathrm{C}_{2}-\mathrm{C}_{4}$ with time on stream. 
Table 6 Oxygenate product distribution in aqueous samples.

\begin{tabular}{ccc}
\hline Oxygenates & $\begin{array}{c}\text { e-Cu-K/Engelhard } \\
\text { mol\% }\end{array}$ & $\begin{array}{c}\text { Fe-Cu-K/Albemarle } \\
\text { C mol\% }\end{array}$ \\
\hline acetaldehyde & 4.2 & 6.3 \\
methyl formate & 1.4 & 2.9 \\
propanal & 2.8 & 3.7 \\
acetone & 0.7 & 1.1 \\
methyl acetate & 22.8 & 37.4 \\
butanal & 0.2 & 0.4 \\
ethyl acetate & 2.1 & 8.3 \\
C1-OH & 1.7 & 1.4 \\
i-propanol & 0.2 & 0.6 \\
C2-OH & 41.9 & 4.8 \\
pentanal & 0.9 & 1.2 \\
2-butanol & 0.3 & 0.3 \\
C3-OH & 12.2 & 16.2 \\
2-methyl-1- & & \\
propanol & 0.8 & 4.3 \\
2-pentanol & 0.1 & 0.1 \\
C4-OH & 2.6 & 3.2 \\
2-methyl-1-butanol & 0.4 & 0.6 \\
2-hexanol & 0.1 & 0.2 \\
C5-OH & 1.5 & 2.3 \\
2-Me-1-pentanol & 0.1 & 0.5 \\
4-Me-1-pentanol & 0.2 & 0.3 \\
3-Me-1-pentanol & 0.1 & 0.1 \\
C6-OH & 1.6 & 2.4 \\
C7-OH & 1.1 & 1.4 \\
& &
\end{tabular}

The CO conversion was higher on Engelhard-spent FCC catalyst with low selectivities towards $\mathrm{CO}_{2}$ and $\mathrm{CH}_{4}$ and high selectivity for the formation of $\mathrm{C}_{5}+$ hydrocarbons in comparision to Albemarle-spent FCC catalyst. This can be attributed to the greater extent of carbide formation on the Engelhard-spent FCC catalyst[38], which can be observed from least square fitting of XANES results (Table-4). The presence of different concentrations of trace metals in the spent FCC support ( Table 2) might also contribute to the different product distribution. 
Our preliminary studies on the Fe catalysts supported over spent FCC materials with Ruhrchemie composition using incipient wetness shows F-T synthesis activity with appreciable attrition resistance. Results obtained in this study using spent FCC catalyst as supports are encouraging; however, the stability of the catalyst should improve prior to commercial use since the deactivation rate is severe. Further optimization of the Fe-spent FCC catalyst, specifically, to improve $\alpha$ and catalyst deactivation, via chemical promotion should be investigated in future studies. Further studies in our laboratory are directed towards the optimization of Fe loading and to compare the F-T activity and attrition resistance of Fe-spent FCC catalysts with commercial Fe F-T catalysts.

\subsection{CONCLUSIONS}

Both spent FCC (Engelhard \& Albemarle) supported Fe catalysts showed appreciable attrition resistance. It is concluded from the F-T activity results, that Fe can be loaded onto spent FCC materials and are active in F-T synthesis. Engelhard (spent FCC) supported Fe-Cu-K catalyst showed good attrition resistance and high $\mathrm{C}_{5}+$ hydrocarbons selectivity in comparison to spent FCC (Albemarle) supported catalyst.

\section{Literature References}

[1] R.B. Anderson, The Fischer-Tropsch Synthesis, Academic press, Orlando, FL, 1984.

[2] M.E. Dry, The Fischer-tropsch synthesis, in J.R. Anderson, M. Boudart (Eds.), Catalysis: Science and Technology, vol. 1, 1981, pp. 159-255.

[3] B.H. Davis, Ind. Eng. Chem. Res. 46 (2007) 8938-8945.

[4] K. Jothimurugesan, J.G. Goodwin, S.K. Santosh, J.J. Spivey, Catal. Today 58 (2000) $335-344$. 
[5] Y.M. Jin, A.K. Datye, J. Catal. 196 (2000) 8-17.

[6] B. Jager, R.L. Espinoza, Catal. Today 23 (1995) 17-28.

[7] C.S. Huang, L. Xu, B.H. Davis, Fuel Sci. Technol. Int. 11 (1993) 639-664.

[8] R.L. Espinoza, A.P. Steynberg, B. Jager, A.C. Vosloo, Appl. catal. A: Gen, 186 (1999) $13-26$.

[9] M.E. Dry, Catal. Today 71 (2002) 227-241.

[10] D.B. Bukur, Development of Improved Iron Fischer-Tropsch Catalysts, technical report DOE/PC/89868, February 1994

[11] H.N. Pham A.K. Datye, Catal. Today 58 (2000) 233-240.

[12] D.S. Kalakkad, M.D. Shroff, S. Kohler, N. Jackson, A.K. Datye, Appl. Catal. A: Gen 133 (1995) 335-350.

[13] R. Zhao, J.G. Goodwin, K. Jothimurugesan, S.K. Gangwal, J.J. Spivey, Ind. Eng. Chem. Res. 40 (2001) 1065-1075.

[14] B. Jager, P Van Berge, A.P. Steynberg, Stud. Surf. Sci. Catal. 136 (2001) 63-68.

[15] H. N. Pham A. Viergutz, R.J. Gormley, A.K. Datye, Powder Technol. 110 (2000) 196203.

[16] R. Srinivasan, L. Xu, R.L. Spicer, F.L. Tungate, B.H. Davis, Fuel Sci. Technol. Int. 14 (1996) 1337-1359.

[17] R.J. O'Brien, L. Xu, S. Bao, A. Raje, B.H. Davis, Fuel Sci. Technol. Int. 196 (2000) 173178.

[18] A.K. Datye, M.D. Shroff, Y. Jin, R.P. Brooks, M.S. Harrington, A.G. Sault, N.B. Jackson, Stud. Surf. Sci. Catal. 101 (1996) 1421-1430. 
[19] K. Jothimurugesan, J.J. Spivey, S.K. Gangwal, J.G. Goodwin, Stud. Surf. Sci. Catal. 119 (1998) 215-220.

[20] S.K. Gangwal, K. Jothimurugesan, U.S. Patent 5,928,980 (1999)

[21] Y.H. Lin, M.H. Yang, Thermochim. Acta 470 (2008) 52-59.

[22] E.I. Basaldella, J.C. Paladino, M. Solari, G.M. Valle, Appl. Catal. B: Environ. 66 (2006) $186-$

[23] A.N. Pour, S.M.K. Shahri, Y. Zamani, M. Irani, S. Tehrani, J. Nat. Gas Chem. 17 (2008) $242-248$.

[24] E.S. Lox, G.B. Marin, E.D. Grave, P. Bussiere, Appl. Catal. A: Gen 40 (1988) 197-218.

[25] D.B. Bukur, L. Nowicki, S.A. Patel, Can. J. Chem. Eng. 74 (1996) 399-404.

[26] S. Li, G.D. Meitzner, E. Iglesisa, J. Phys. Chem. B 105 (2001) 5743-5750.

[27] B. Ravel, M. Newville, J. Synchrotron Rad. 12 (2005) 537-541.

[28] R. Zhao, J.G. Goodwin, R. Oukaci, Appl. Catal. A: Gen 186 (1999) 255-275.

[29] R. Zhao, K. Sudsakorn, J.G. Goodwin, K. Jothimurugesan, S.K. Gangwal, J.J. Spivey, Catal. Today 71 (2002) 319-326.

[30] C.H. Zhang, Y. Yang, B.T. Teng, T.Z. Li, H.Y. Zheng, H.W. Xiang, Y.W. Li, J. Catal. 237 (2006) 405-415.

[31] J. Yang, Y. Sun, Y. Tang, Y. Liu, H. Wang, L. Tian, Z. Zhang, H. Xiang, Y.W. Li, J. Mol. Catal. A: Chem 245 (2006) 26-.

[32] S. Li, A. Li, S. Krishnamoorthy, E. Iglesia, Catal. Lett. 77 (2001) 197-205.

[33] S.R. Wasserman, J. de Physique IV 1 (1997) 203-205.

[34] J. Xu, C.H. Bartholomew, J. Phys. Chem. B 109 (2005) 2392-2403.

[35] S. Li, W. Ding, G.D. Meitzner, E. Iglesia, J. Phys. Chem. B 106 (2002) 85-91. 
[36] S. Li, R.J. O’Brien, G.D. Meitzner, H. Hamdeh, B.H. Davis, E. Iglesia, Appl. Catal. A: Gen 219 (2001) 215-222.

[37] R. Zhao, J.G. Goodwin, K. Jothimurugesan, J.J. Spivey, S.K. Gangwal, Ind. Eng. Chem. Res. 39 (2000) 1155-1158.

[38] E.de Smit, B.M.Weckhuysen, Chem. Soc. Rev. 37 (2008) 2758-2781

[39] D.B. Bukur,C. Sivaraj, Appl. Catal.A: Gen. 231 (2002) 201-214.

[40] R.J. O'Brien, L.Xu.S. Bao.A. Raje, B.H. Davis, Appl. Catal, A: Gen. 196 (2000) 173-.

[41] W. Hou, B,Wu, Y. Yang. Q. Hao, L, Tian, H.Xiang, Y. Li, Fuel Sci. Technol,89 (2008) 284-291.

[42] M. Luo, B.H. Davis, Fuel Process. Technol. 83 (2003) 49-65. 